УДК 633.11:368:631.53.027

(C) 2013

Герман М. М., здобувач,

Маренич М. М., кандидат сільськогосподарських наук

Полтавська державна аграрна академія

\title{
ЕФЕКТИВНІСТЬ ПЕРЕДПОСІВНОЇ ОБРОБКИ НАСІННЯ ФОСФАТМОБІЛІЗУЮЧИМИ ПРЕПАРАТАМИ ПШЕНИЦІ М'ЯКОї ОЗИМОї
}

\section{Рецензент - кандидат сільськогосподарських наук О. В. Міщенко}

\begin{abstract}
Встановлено, щзо передпосівна обробка насіння пиениці м'якої озимої сорту Василина фосфатмобілізуючими препаратами позитивно сприяє збільшенню врожайності зерна пшениці озимої. 3 а даними наукових досліджень встановлено найвищиий приріст врожайності пшениці м'якої озимої за застосування бактеріальних речовин «Полімік-

собактерин» та «Діазофіт» у дозі 150 мл/m, за внесення повного мінерального добрива в дозі $N_{25} P_{25} K_{25}-$ на 0,95, $N_{50} P_{50} K_{50}-$ на 0,95, $N_{75} P_{75} K_{75}-$ на 0,85, а за внесення $3 \mathrm{~m} / 2$ а соломи із підживленням $N_{10}-$ на 0,94. "Діазофіт» за внесення повного мінерального добрива в дозі без добрив дає приріст врожайності на $0,86, N_{25} P_{25} K_{25}-$ на 0,93, $N_{50} P_{50} K_{50}$ - на 0,94, $N_{75} P_{75} K_{75}-$ на 0,87,3, соломи $+N_{10}-$ на $1,01 \mathrm{~m} / \mathrm{aa}$.
\end{abstract}

Ключові слова: фосфатмобілізуючі препарати, приріст врожаю, поліміксобактерин, регулятори росту, мінеральні добрива, інокулячія насіння.

Постанова проблеми. У сучасному землеробстві існує агроекологічний напрям, який передбачає застосування нових технологій вирощування сільськогосподарських культур, що забезпечують одержання екологічно чистої і біологічно повноцінної продукції рослинництва. Високу екологічну й економічну ефективність цих технологій обумовлюють мікробні препарати, які здатні поліпшувати азотне та фосфорне живлення рослин. В технології біологічного землеробства широко використовується оброблення насіння бактеріальними препаратами поліфункціональної дії, здатними позитивно впливати на фізіологічні процеси, що відбуваються в рослинах, i завдяки цьому сприяти підвищенню продуктивності сільськогосподарських культур

Аналіз основних досліджень і публікацій, у яких започатковано розв'язання проблеми. У вирішенні важливого завдання збереження та відновлення родючості грунту необхідно враховувати особливості мікробіологічних процесів, які проходять у ньому, та вміло використовувати заходи, що регулюють їх активність [1]. Відомо, що насичення сівозмін окремими культурами та внесення невиправдано високих доз мінеральних добрив сприяють підвищенню мінералізуючої активності мікробних угруповань, що призводить до значних втрат гумусу і зниження родючості грунту [5]. Альтернативні технології вирощування сільськогосподарських культур, які передбачають максимальне використання біологічних факторів, формують стабільну структуру трофічних зв'язків у мікробних ценозах, збільшують їх стійкість та інтегрованість [6].

Одним із елементів біологізації сучасного землеробства $\epsilon$ використання біопрепаратів на основі ефективних штамів мікроорганізмів, які покращують азотне та фосфорне живлення культурних рослин [4]. Крім того мікробні препарати сприяють зростанню чисельності мікроорганізмів окремих еколого-трофічних груп у ризосферному грунті, що опосередковано свідчить про метаболічні зміни [2].

Метою нашої роботи було дослідити ефективність допосівної обробки насіння регулятором росту «Вимпел» $\mathrm{i}$ «Агат- 25 К», протруйника «Віал ТТ» та фосфатмобілізуючих препаратів «Поліміксобактерин» і «Діазофіт» у підвищенні врожайності насіння пшениці м'якої озимої.

Завдання досліджень - встановити вплив передпосівної обробки насіння регулятором росту, протруйника та фосфатмобілізуючих препаратів на підвищення врожайності пшениці м'якої озимої в Полтавській області.

Матеріали і методи досліджень. «Поліміксобактерин» (виробник - інститут сільськогосподарської мікробіології УААН) рекомендовано для поліпшення фосфорного живлення та підвищення урожайності пшениці озимої на 11-28 \%. Препарат містить бактерії штаму Bacillus polymyха $\mathrm{KB}$, титр - 55 Х10 клітин/г сухої форми. «Діазофіт» (виробник - інститут сільськогосподарської мікробіології УААН) забезпечує зростання урожайності сільськогосподарських культур на 15-20 \% 
та поліпшення якості продукції. Препарат містить азотфіксуючі бактерії Agrobacterium radiobacter. «Вимпел» (виробник - МПНДП «Долина», Україна) покращує ріст і розвиток рослин, сприяє активному розвитку кореневої системи, що збільшує урожай на 10-30\%. Препарат містить ПЕГ-400 - 230 г/л; ПЕГ-1500 - 540 г/л; гумат натрію - 30 г/л. «Агат-25К» (виробник - «Венд», Україна) значно підвищує польову схожість, збільшує енергію проростання насіння. Препарат містить інактивовані бактерії Pseudomonas aureofaciens штаму Н16 - 2 \%, біологічно активні речовини культуральної рідини - $38 \%$, а-глутамінова кислота - 70 мг/кг + а-аланін - 60 мг/кг + 3-індоліло-цетова кислота - 18 мг/кг.
«Віал ТТ» (протруйник; виробник - «Август») пригнічує розвиток грибів - збудників хвороб, які містяться на поверхні насіння, а також тих, що розвиваються всередині нього. Препарат містить 60 г/л тебуконазолу і 80 г/л тіабендазолу.

Дослідження 3 пшеницею м'якою озимою сорту Василина проведено впродовж 2008-2010 рр. в умовах Лівобережного Лісостепу на базі дослідного поля Полтавського інституту агропромислового виробництва ім. М. І. Вавилова. Повторність - триразова, попередник - горох; норма висіву насіння - 5,0 млн схожих насінин на 1 га, глибина загортання насіння - 4-6 см. Сівбу проводили у третій декаді вересня, в залежності від погодних умов даного періоду в рік сівби сівалкою С3-3,6.

\section{Урожайність зерна пшениці м'якої озимої сорту Василина залежсно від обробки насіння біологічно активними речовинами (середнс за 2008-2010 рр.)}

\begin{tabular}{|c|c|c|c|}
\hline $\begin{array}{c}\text { Допосівна обробка насіння } \\
\text { (фактор А) }\end{array}$ & $\begin{array}{c}\text { Bаріанти удобрення } \\
\text { (фактор Б) }\end{array}$ & $\begin{array}{c}\text { Урожайність, } \\
\text { т/га }\end{array}$ & $\begin{array}{c}\text { Приріст } \\
\text { урожайності, т/га } \pm\end{array}$ \\
\hline \multirow{5}{*}{$\begin{array}{c}\text { Без обробки насіння } \\
\text { контроль }\end{array}$} & Без добрив & 4,81 & - \\
\hline & $\mathrm{N}_{25} \mathrm{P}_{25} \mathrm{~K}_{25}$ & 5,71 & - \\
\hline & $\mathrm{N}_{50} \mathrm{P}_{50} \mathrm{~K}_{50}$ & 5,87 & - \\
\hline & $\mathrm{N}_{75} \mathrm{P}_{75} \mathrm{~K}_{75}$ & 5,98 & - \\
\hline & 3 т/га соломи $+\mathrm{N}_{10}$ & 5,55 & - \\
\hline \multirow{5}{*}{$\begin{array}{c}\text { Протруєння насіння «Віалом», } \\
0,4 \pi / \mathrm{T}\end{array}$} & Без добрив & 5,17 & $+0,36$ \\
\hline & $\mathrm{N}_{25} \mathrm{P}_{25} \mathrm{~K}_{25}$ & 6,35 & $+0,64$ \\
\hline & $\mathrm{N}_{50} \mathrm{P}_{50} \mathrm{~K}_{50}$ & 6,57 & $+0,70$ \\
\hline & $\mathrm{N}_{75} \mathrm{P}_{75} \mathrm{~K}_{75}$ & 6,69 & $+0,71$ \\
\hline & $3 \mathrm{t} /$ га соломи $+\mathrm{N}_{10}$ & 6,17 & $+0,62$ \\
\hline \multirow{5}{*}{$\begin{array}{c}\text { Оброблене насіння } \\
\text { регуляторами росту* }\end{array}$} & Без добрив & 5,78 & $+0,97$ \\
\hline & $\mathrm{N}_{25} \mathrm{P}_{25} \mathrm{~K}_{25}$ & 6,32 & $+0,61$ \\
\hline & $\mathrm{N}_{50} \mathrm{P}_{50} \mathrm{~K}_{50}$ & 6,30 & $+0,43$ \\
\hline & $\mathrm{N}_{75} \mathrm{P}_{75} \mathrm{~K}_{75}$ & 6,50 & $+0,52$ \\
\hline & $3 \mathrm{t} /$ га соломи $+\mathrm{N}_{10}$ & 6,16 & $+0,61$ \\
\hline \multirow{5}{*}{$\begin{array}{c}\text { Оброблене насіння бактеріаль- } \\
\text { ним препаратом «Поліміксо- } \\
\text { бактерин», } 150 \text { мл/т }\end{array}$} & Без добрив & 5,70 & $+0,89$ \\
\hline & $\mathrm{N}_{25} \mathrm{P}_{25} \mathrm{~K}_{25}$ & 6,66 & $+0,95$ \\
\hline & $\mathrm{N}_{50} \mathrm{P}_{50} \mathrm{~K}_{50}$ & 6,82 & $+0,95$ \\
\hline & $\mathrm{N}_{75} \mathrm{P}_{75} \mathrm{~K}_{75}$ & 6,83 & $+0,85$ \\
\hline & $3 \mathrm{~T} /$ га соломи $+\mathrm{N}_{10}$ & 6,49 & $+0,94$ \\
\hline \multirow{5}{*}{$\begin{array}{c}\text { Оброблене насіння бактеріаль- } \\
\text { ним препаратом «Діазофіт», } \\
150 \text { мл/т }\end{array}$} & Без добрив & 5,67 & $+0,86$ \\
\hline & $\mathrm{N}_{25} \mathrm{P}_{25} \mathrm{~K}_{25}$ & 6,64 & $+0,93$ \\
\hline & $\mathrm{N}_{50} \mathrm{P}_{50} \mathrm{~K}_{50}$ & 6,81 & $+0,94$ \\
\hline & $\mathrm{N}_{75} \mathrm{P}_{75} \mathrm{~K}_{75}$ & 6,85 & $+0,87$ \\
\hline & 3 т/га соломи $+\mathrm{N}_{10}$ & 6,56 & $+1,01$ \\
\hline \multicolumn{2}{|c|}{ HIP 05 фактор A } & 1,96 & \\
\hline \multicolumn{2}{|c|}{ HIP ${ }_{05}$ фактор B } & 1,96 & \\
\hline \multicolumn{2}{|c|}{ Взаємодї $A B$} & 5,71 & \\
\hline
\end{tabular}

Примітка: * - без добрив, оброблені «Вимпелом» (150 мл/т), $\mathrm{N}_{25}$ - сумісної обробки «Вимпелом» $\left(90\right.$ мл/т) i «Агатом-25К» $\left(25\right.$ г/т), $\mathrm{N}_{50}-$ «Агат-25К» $\left(40\right.$ г/т), $\mathrm{N}_{75}-$ «Вимпел» $(120$ мл/т) i «Агат-25К» $\left(60\right.$ г/т), $\mathrm{N}_{10}-\ll$ «импел» $(100$ мл/т) i «Агат-25К» $(20$ г/т). 
Перед сівбою насіння обробляли протруйником «Віал» $(0,4$ л/т), ріст стимулюючими речовинами «Вимпел» $(150$ мл/т), «Агат-25К» $(40$ г/т), а також сумісно обробляли «Вимпелом» $(90$ мл/т) $\mathrm{i}$ «Агатом-25К» $(25$ г/т), «Вимпелом» $(120$ мл/т) i «Агатом-25К» $(60$ г/т), «Вимпелом» $(100$ мл/т) i «Агатом-25К» (20 г/т) та проводили передпосівну інокуляцію бактеріальними препаратами («Поліміксобактерин» і «Діазофіт») у дозі $150 \mathrm{mл} / \mathrm{T}$ із витратою робочої речовини 2 л/га. Навесні вносили азотне добриво по варіантах: $\mathrm{N}_{25}, \mathrm{~N}_{50}, \mathrm{~N}_{75}$ по мерзлоталому грунту, в період відновлення вегетації. Облік урожайності проводили методом поділянкового обмолоту з наступним очищенням зерна і перерахунком на $100 \%$ чистоту та на $14 \%$ вологість, які визначали відповідно до Методики державного сортовипробування [3].

Результати досліджень. Головним критерієм, котрий дає можливість комплексно оцінити ефективність технологічних заходів вирощування сільськогосподарських культур, $\epsilon$ врожайність зерна. Узагальнена врожайних даних у досліді показало, що максимальний приріст урожайності залежить від погодних умов, мінерального живлення і допосівної обробки насіння. За даними наших досліджень встановлено, що передпосівна інокуляція насіння пшениці м'якої озимої поліміксобактерином і діазофітом забезпечила одержання додаткового врожаю (див. табл.).

Так, за час проведення дослідження отримання максимальної врожайності за обробки насіння протруйником «Віал ТТ» приріст врожаю становив 0,36 без добрив, за внесення повного мінерального добрива в дозі $\mathrm{N}_{25} \mathrm{P}_{25} \mathrm{~K}_{25}-0,64, \mathrm{~N}_{50} \mathrm{P}_{50} \mathrm{~K}_{50}$ $-0,70, \mathrm{~N}_{75} \mathrm{P}_{75} \mathrm{~K}_{75}-0,71$, а за внесення 3 т/га соломи і підживлення $\mathrm{N}_{10}-0,62.3$ використанням регуляторів росту спостерігалося активне сприяння приросту врожаю. За даними наукових досліджень, оброблене «Вимпелом» (150 мл/т) насіння збільшило приріст врожаю на 0,97, $\mathrm{N}_{25} \mathrm{P}_{25} \mathrm{~K}_{25}$ за сумісної обробки «Вимпелом» $\left(90\right.$ мл/т) і «Агатом-25K» $\left(25\right.$ г/т) - на $0,61, \mathrm{~N}_{50} \mathrm{P}_{50} \mathrm{~K}_{50}$

\section{БІБЛІОГРАФІЯ}

1. Андреюк Е. И., Путинская Г. А., Дульгеров А. Н. Почвенные микроорганизмы и интенсивное землепользование. - К. : Наукова думка, 1988. - 197 с. 2. Волкогон В. В., Надкернична О. В., Ковалевські Т. М. Мікробні препарати у землеробстві // Теорія і практика - К. : Аграрна наука, 2006. - 312 с.

3. Методика державного сортовипробування сільськогосподарських культур. - Вип. 4. - К., 2001. - C. 29-30.
«Агат-25К» (40 г/т) - на 0,43, $\mathrm{N}_{75} \mathrm{P}_{75} \mathrm{~K}_{75}$ - «Вимпел» $(120$ мл/т) i «Агат-25К» $(60$ г/т) - на 0,52 , а за внесення 3 т/га соломи із підживленням $\mathrm{N}_{10}$ «Вимпел» $(100$ мл/т) i «Агат-25К» $(20$ г/т) приріст врожаю зріс на 0,61 .

Допосівна обробка насіння «Поліміксобактерином» сприяла зростанню приросту врожаю за внесення повного мінерального добрива: без добрив - на $0,89, \mathrm{~N}_{25} \mathrm{P}_{25} \mathrm{~K}_{25}$ - на $0,95, \mathrm{~N}_{50} \mathrm{P}_{50} \mathrm{~K}_{50}$ - на $0,95, \mathrm{~N}_{75} \mathrm{P}_{75} \mathrm{~K}_{75}-$ на $0,85,3$ т/га соломи $+\mathrm{N}_{10}-$ на 0,94. «Діазофіт» за внесення повного мінерального добрива в дозі без добрив дав приріст врожаю на $0,86, \mathrm{~N}_{25} \mathrm{P}_{25} \mathrm{~K}_{25}$ - на $0,93, \mathrm{~N}_{50} \mathrm{P}_{50} \mathrm{~K}_{50}$ - на $0,94, \mathrm{~N}_{75} \mathrm{P}_{75} \mathrm{~K}_{75}-$ на $0,87,3$ т/га соломи $+\mathrm{N}_{10}-$ на 1,01 , порівняно 3 контрольним варіантом, регуляторами росту та протруєнням насіння.

\section{Висновки:}

1. Встановлено, що передпосівна обробка насіння пшениці м'якої озимої сорту Василина фосфатмобілізуючими препаратами позитивно сприяє збільшенню врожайності зерна пшениці озимої.

2. За результатами проведених досліджень встановлено, що азотне підживлення по мерзлоталому грунту $\mathrm{N}_{25} \mathrm{P}_{25} \mathrm{~K}_{25}, \mathrm{~N}_{50} \mathrm{P}_{50} \mathrm{~K}_{50}, \mathrm{~N}_{75} \mathrm{P}_{75} \mathrm{~K}_{75}$ та передпосівна інокуляція насіння рістстимулюючими та біологічно активними речовинами («Вимпел» + «Агат-25К», «Поліміксобактерин» та «Діазофіт») сприяє збільшенню врожайності.

3. За даними наукових досліджень встановлено найвищий приріст врожайності пшениці м'якої озимої за застосування бактеріальних речовин «Поліміксобактерин» та «Діазофіт» у дозі 150 мл/т, за внесення повного мінерального добрива в дозі $\mathrm{N}_{25} \mathrm{P}_{25} \mathrm{~K}_{25}-$ на $0,95, \mathrm{~N}_{50} \mathrm{P}_{50} \mathrm{~K}_{50}-$ на $0,95, \mathrm{~N}_{75} \mathrm{P}_{75} \mathrm{~K}_{75}$ - на 0,85 , а за внесення 3 т/га соломи із підживленням $\mathrm{N}_{10}-$ на 0,94 т/га. «Діазофіт» за внесення повного мінерального добрива в дозі без добрив дає приріст врожайності на $0,86, \mathrm{~N}_{25} \mathrm{P}_{25} \mathrm{~K}_{25}$ - на $0,93, \mathrm{~N}_{50} \mathrm{P}_{50} \mathrm{~K}_{50}$ - на 0,94 , $\mathrm{N}_{75} \mathrm{P}_{75} \mathrm{~K}_{75}-$ на 0,87,3, соломи $+\mathrm{N}_{10}-$ на 1,01 т/га.

4. Патика В. П., Кочь С. Я., Волкогон В. В. [та ін.]. Біологічний азот. - К. : Світ, 2003.- 422 с.

5. Путинская Г. А., Остапенко А. Д., Андреюк Е. И. Устойчивость микробных сообществ почвы под озимой пшеницей при разных аротехнологиях ее возделывания // Микробиол. журн. - 1993. T. 55, № 2. - C. 3-7.

6. Шикула М. К. Охорона грунтів / М. К. Шикула // Навчальний посібник. - К. : Знання, 2004. - 398 с. 